\title{
10
}

\section{Emergent Trends in Indigenous Labour Mobility: Flying to Work in the Nation's Quarry}

\author{
Sarah Prout Quicke and Fiona Haslam McKenzie
}

As a phenomenon, contemporary Indigenous mobility and migration resulting from employment in the mainstream labour market is relatively obscured in Australia's public and scholarly consciousness. Given the 'mobile turn' in the social sciences, ${ }^{1}$ the 'cultural turn' within migration studies, ${ }^{2}$ the long legacy of Indigenous labour mobility and the central, though highly contested, place of mainstream employment in Australia's current Indigenous affairs policy agenda, ${ }^{3}$ this obscurity is surprising.

Within a neoliberal political economy, legislative and policy reforms and Indigenous responses to them, have engendered important policy debates with respect to Indigenous economies and broader questions of social and spatial justice. ${ }^{4}$ These debates have centred on the role of the state as welfare provider, Indigenous 'mainstreaming', 5 and the relative

Sheller and Urry, 'The New Mobilities Paradigm'.

Blunt, 'Cultural Geographies of Migration'; King, 'Geography and Migration Studies'.

Curchin, 'Two Visions'.

Altman, 'What Future for Remote Indigenous Australia?'; Altman, 'Indigenous Policy'; Curchin, 'Interrogating the Hybrid Economy Approach'; Curchin, 'Two Visions'.

5 This term refers broadly to the current federal ideological approach to Indigenous affairs policy, characterised by a deliberate shift away from previous approaches that provided for Indigenousspecific services and programs for Indigenous peoples. Many of these programs and services have been discontinued and Indigenous peoples have been incorporated into existing 'mainstream' service delivery models and programs. 
'viability' and wellbeing of remote Indigenous communities with limited access to formal educational and market opportunities. ${ }^{6}$ These debates and discussions are of critical importance in terms of policymaking. However, their central subjects tend to be Indigenous peoples who are not engaged in mainstream labour markets. The experiences and outcomes of Indigenous peoples who move or migrate because of direct engagement with the mainstream labour market have remained relatively unexamined. That is to say, the contemporary mobile (or migrant) Indigenous labouring subject is rarely the focus of empirical analysis.

This labouring subject has also been largely absent in the Indigenous mobility literature. This literature has addressed important questions of social and spatial justice for Indigenous peoples that revolve around the ways in which Indigenous peoples are often constructed as out of place and/or inauthentic and ungovernable because of their mobility. ${ }^{7}$ It surfaces a powerful settler logic that holds that being settled and/or economically productive (narrowly defined within a neoliberal political economy as engaged with mainstream markets) are fundamental pillars of responsible citizenship. In the policy era of neoliberal mainstreaming, remote living can be constructed as a barrier to such citizenship. Geographical movement towards mainstream markets can appear to be an implicit goal of policies and programs that concentrate Indigenous affairs investment and services in larger cities, towns and communities. However, the available evidence suggests that there is no trend of Indigenous peoples moving towards localities with greater employment opportunities. ${ }^{8}$

The Indigenous mobilities literature also traces a range of Indigenous mobility and migration practices associated with customary and cultural activities, as well as the need and desire to access a range of health, housing, education, welfare, recreational and retail services. ${ }^{9}$ Of course, if we consider the compelling call of feminist scholars to value processes of social reproduction as forms of real work, many of these movements are, in fact, kinds of labour mobility. ${ }^{10}$ Nevertheless, our central point is that the Indigenous mobilities literature seldom, if ever, addresses the more narrow kind of labour mobility with which this chapter is concerned:

6 Biddle, 'Proximity to Labour Markets'.

7 Prout and Howitt, 'Frontier Imaginings'.

8 Biddle, 'Indigenous Migration and the Labour Market'; Taylor, 'Population and Diversity'.

9 Dockery, 'A Wellbeing Approach'; Musharbash, Yuendumu Everyday; Prout, 'Interrogating the Image'; Taylor and Bell, Population Mobility and Indigenous Peoples.

10 McDowell, 'The Lives of Others'; Silvey, 'Power, Difference and Mobility'. 
movement because of mainstream labour market employment. Such movements include, but are not limited to, relocating a usual residence to look for or commence a job, long-distance commuting and regular travel associated with mainstream employment. ${ }^{11}$

This chapter seeks to develop the conceptual terrain of these kinds of contemporary Indigenous labour mobilities in Australia by foregrounding the experiences and outcomes of one case study group of Indigenous mobile workers: fly-in fly-out (FIFO) mine employees based at Broome in the West Kimberley region of Western Australia. We make two central, but related, claims. First, there are important similarities and differences between contemporary Indigenous FIFO work and historical Indigenous labour mobility practices. We suggest that Indigenous FIFO mine work is simply a new(er) expression of well-established practices of labour mobility among Indigenous Australians prior to, and since, colonisation. Though, there are also important differences across time and space. Second, Indigenous FIFO workers occupy a unique position on the labour mobility spectrum. Though they often fill lower skilled roles in the sector and thus constitute a precariat of sorts, they do not face the same challenges with respect to exploitation and financial expropriation as many lower skilled transnational labour migrants, including the Pacific Islanders discussed by Stead, and Nishitani and Lee, in this volume. ${ }^{12}$ However, neither are their labour mobilities characteristic of the privileged class of highly mobile professionals that Cresswell, Dorow and Roseman refer to as the 'kenetic elite'. ${ }^{13}$

Indigenous FIFO work represents a significant shift from the exploitative and coercive experiences associated with direct colonial subjugation. Today, these labourers are sought after within the resource sector in Australia and have access to the same suite of legislative protections as all other Australians in the mainstream labour market. Nevertheless, their labour mobilities are shaped by a representational politics that is imbued with the coloniality of power. ${ }^{14}$ Consequently, FIFO workers still face a unique set of precarities, vulnerabilities and challenges associated with their labour mobility.

11 Productivity Commission, Geographic Labour Mobility.

12 Buckley, McPhee and Rogaly, 'Labour Geographies'; Preibisch, 'Pick-Your-Own Labour'.

13 Cresswell, Dorow and Roseman, 'Putting Mobility Theory'.

14 Stead and Altman, this volume. 


\section{The Historical Legacy of Indigenous Labour Mobility}

There is now a rich historical literature, including chapters in this volume (particularly Shino Konishi's), that clearly identifies both pre- and postsettlement practices of Indigenous temporary, circular mobilities related to labour, resource harvesting, management and trade. For example, historians have examined the pre-colonial importance of transnational Macassan ${ }^{15}$ and domestic trade networks ${ }^{16}$ for Indigenous people living in the country's north. In these systems, Indigenous people were not 'fixed' in time and space, or economically primitive and insular. Rather, in their harvesting and trade practices, mobility and economy were demonstrably enmeshed.

The arrival of British colonists led to the disruption and eventual cessation of some of these practices. It also introduced new forms of Indigenous labour mobility. Roseman, Barber and Nei note that one of the chief historical drivers of labour mobility, particularly under conditions of European colonialism, was the dislocation of people and groups from the homelands from which they had previously derived their livelihoods. ${ }^{17}$ Responding to dislocation and opportunity, Indigenous Australians made vital, yet often deeply exploited, contributions to early colonial maritime industries, such as sealing and whaling enterprises in southern Australia ${ }^{18}$ and pearling enterprises in the north. ${ }^{9}$

The colonial frontier extended its reach in Western Australia's northern Kimberley region in the late 1800 s as pastoral leases were granted and the township of Broome was established as a pearling port. Many Aboriginal people worked both as stockmen and domestic staff for non-Aboriginal pastoralists, sometimes receiving a small wage or basic provisions. ${ }^{20}$ Commercial pearling operations were also expanded along the West Kimberley coast with Aboriginal people, especially women, favoured as divers. Malay, Chinese, Japanese, Filipino, Amborese, Koepanger (Timorese) and Macassan divers-many of whom travelled regularly to the region as part of long-standing prior trade networks-

15 Lydon, 'Picturing Macassan-Australian Histories'.

16 Redmond, 'Tracking Wurnan'; Redmond and Skyring, 'Exchange and Appropriation'.

17 Roseman, Barber and Nei, 'Towards a Feminist'.

18 Russell, “"The Singular Transcultural Space”.

19 Keen, 'Introduction'.

20 Bolton, 'Alexander Forrest's Expedition 1879'. 
were subsequently exploited, usually coercively through indentured labour arrangements, as divers, deckhands, cooks and onshore workers. By 1910, more than 3,500 people on almost 400 pearling luggers were fishing for pearls and shell around Broome, making it one of the world's largest pearling centres. ${ }^{21}$ Pearl diving was dangerous work and these operations sometimes displaced workers thousands of kilometres from their homelands with no promise of eventual safe return.

As the pearling and pastoral industries developed, Catholic missions were also established in three West Kimberley communities: Beagle Bay, Lombadina and Broome. The locally practised Pallotine method of missionary engagement was for clergy and lay people to work in partnership. In some cases, Aboriginal languages, customs and spiritual beliefs coexisted alongside missionary activities that established educational and employment enterprises. ${ }^{22}$ Workshops and trade schools were developed to train local Aboriginal men in building skills, farming, shoe making and blacksmithing, while the women were taught to launder, sew and cook and and learned rudimentary skills in Western medical practice. Reading, writing, mathematics, history and music were also an important part of the curriculum. ${ }^{23}$ The experiences for mission residents were mixed, but many would later report that the education and skills prepared them for life in a settler-dominant world. ${ }^{24}$

Until the late 1960s, labour opportunities in the emergent pastoral industry (largely unpaid or underpaid) ${ }^{25}$ and in building the colony's transport infrastructure (particularly railways and roads) saw large numbers of Indigenous peoples moving regularly across and between pastoral stations, and sometimes to regions a considerable distance from their homelands, to follow available work. Significant changes to Indigenous labour mobility practices in the Kimberley occurred in the 1960s in response to the civil rights movement abroad and domestically. The hard-fought introduction of equal wages for Indigenous people in the pastoral industry ${ }^{26}$ in 1968 , and the increasing mechanisation of labour

\footnotetext{
21 Hart et al., 'Western Australian Silver-Lipped Pearl Oyster'.

22 Choo, 'Mixed Blessings'; Kelly, Proud Heritage.

23 Choo, 'Mixed Blessings'; Lockyer, Last Truck Out.

24 Choo, 'Mixed Blessings'; Kelly, Proud Heritage; Lockyer, Last Truck Out.

25 See, for example, Stevens, Aborigines in the Northern; Choo, 'Mixed Blessings'.

26 In 1966, the Commonwealth Conciliation and Arbitration Commission handed down a decision to remove racially discriminatory clauses in the federal pastoral award for station workers, which had allowed station owners not to pay Aboriginal workers the standard award wage (Skyring, (Low Wages, Low Rents'). These measures took effect in 1968.
} 
in agriculture, transport and maritime industries saw many Indigenous people displaced from the workforce. ${ }^{27}$ At the same time, social welfare entitlements were broadened for Indigenous people. Of this period, Skyring comments: 'Increased drinking by people in the reserve camps, unemployment and widespread homelessness all happened at roughly the same time for Kimberley Aboriginal people. These changes conflated as one catastrophe. ${ }^{28}$ She notes that some Aboriginal leaders in the Kimberley describe these reforms as having precipitated a refugee crisis in the region, as many displaced workers moved into larger towns, including Broome. $^{29}$ Subsequently, during the 1980s, a federally sanctioned (and funded) outstations movement facilitated the large-scale movement of many Indigenous peoples in the Kimberley back to small homeland communities where there was limited access to an increasingly urbanised and post-industrial mainstream labour market.

This history has produced a contemporary policy emphasis on the failure of past approaches to Indigenous self-determination, the danger of welfare dependence and the economic costs of servicing small remote Indigenous homeland communities in the region. Yet, such policy discourses operate in a relative vacuum with respect to contemporary Indigenous experiences of labour mobility, the decision-making processes that underpin employment-related migration and trajectories, and clear evidence regarding their outcomes.

Contemporary Indigenous FIFO arrangements share some characteristics with historical Indigenous labour mobilities. Like Macassan trade networks, and post-settlement work on pastoral stations in north-west Western Australia, they involve frequent circular mobilities (temporary movements away followed by return), but centre around a strong attachment to, and presence on, customary lands. Further, though the underlying political economy that shapes these labour mobilities has changed significantly over time, FIFO mine labour is globally enmeshed in neoliberal, extractive and externally oriented projects, just as these earlier historical mobilities were.

There are also continuities in Indigenous labour subjectivities. These range from essentialising discourses that characterise Indigenous workers as variously unreliable/lazy, naturally talented or highly malleable,

27 Anthony, 'An Anniversary Shrouded in Myths'.

28 Skyring, 'Low Wages, Low Rents', 157.

29 Skyring, 'Low Wages, Low Rents', 157. 
to a narrow fixation on the gap between Indigenous and non-Indigenous population-to-employment ratios, and disproportionate welfare dependence. ${ }^{30}$ Historically, such subjectivities and discourses produced an under-appreciation of the vital role that Indigenous peoples played in the advancement of the Australian colony. Today, they can be used to de-contextualise, or resist sustained engagement with, the full range of factors driving lower rates of Indigenous labour force participation. ${ }^{31}$ They also obscure the lived experiences of the 46.6 per cent of Indigenous peoples aged 15-64 who are engaged in mainstream work.

However, there are also important differences between historical Indigenous labour mobility practices and contemporary Indigenous FIFO arrangements. Chief among these are contemporary legal protections for Indigenous workers in respect of remuneration, working conditions, and discriminatory employer behaviours, that did not exist during the early colonial era. Historically, Indigenous people working in maritime industries and on pastoral stations often did so under highly exploitative, abusive and restrictive conditions. Indeed, some scholars have described them as feudalistic and based on semi-slavery arrangements. ${ }^{32}$ In many cases, hardship was endured for a range of reasons. Pastoral station work provided an avenue for remaining on country and engendered respect within and outside of the Indigenous community for the skills developed and applied. Other itinerant work provided a means to avoid poverty and/or travel to different regions. However, as a result of a domestic and global civil rights movement in the 1960s, Indigenous peoples today are recognised as equal citizens under the law with the same worker rights, and remuneration standards, as all other citizens when engaged in mainstream employment.

Another significant, and somewhat paradoxical, difference between historical Indigenous labour mobility and contemporary Indigenous FIFO mine work, which we unpack further below, is sector specific and relates to the unique position that Indigenous employees occupy in the Australian mining sector. They are a sought-after, yet often lower skilled, employee sub-population within the industry in Australia. This unique position emerges from a coalescence of differently scaled time and space phenomena. These include global pressures on mining companies to

30 See, for example, Commonwealth of Australia, 'Closing the Gap Prime Minister's Report 2018'.

31 See, for example, Gray, Hunter and Lohoar, 'Increasing Indigenous Employment Rates'.

32 Anthony, 'An Anniversary Shrouded in Myths'; Skyring, 'Low Wages, Low Rents'. 
secure a social licence to operate on the local territories of Indigenous groups, and national-level legislation in Australia that requires mining companies to negotiate compensation and benefits for Indigenous peoples when mining activities occur on lands over which those groups have a registered or recognised claim to native title.

These two developments have resulted in aspirations and obligations within the mining industry to advance Indigenous employment outcomes, often through FIFO arrangements, which we discuss further below. Also of critical contextual importance here are ongoing, intergenerational experiences of disadvantage wrought by historical processes of colonisation that often sought to dislocate Indigenous peoples from kin and country, and excluded them from mainstream educational and properly remunerated employment opportunities. The result is that many Indigenous mining employees today occupy lower skilled jobs in the industry and face a unique set of challenges associated with maintaining and advancing their career pathways.

\section{West Australian Indigenous Labour Mobility in Context}

Data from the 2016 census show that, excluding intra-metropolitan commuting, 13.3 per cent of Western Australia's Indigenous labour force participants worked in a different local government area (LGA) to the one in which they were usually resident. ${ }^{33}$ As Figure 10.1 shows, the most significant flows of this form of work-related mobility were towards the mining-intensive shires of Ashburton, Roebourne, Port Hedland and East Pilbara, indicating the predominance of this industry as a driver of Indigenous labour mobility. Indeed, at the 2016 census, mining was proportionally the largest sector of Indigenous employment in Western Australia, and the proportions had increased over that period. ${ }^{34}$ However, as Figure 10.2 shows, this predominance of mining as a sector of Indigenous employment is not mirrored more broadly in Australia or, more specifically, in the Shire of Broome where there are no mine sites.

33 This figure is based on the authors' calculations using 2016 Australian Bureau of Statistics Census data to compare Indigenous LGA of work with LGA of usual residence. It is, of course, only one measure of labour mobility and does not capture Indigenous peoples commuting beyond Western Australia for work.

34 Australian Bureau of Statistics, 'Indigenous Employment by Industry, 2016'. 


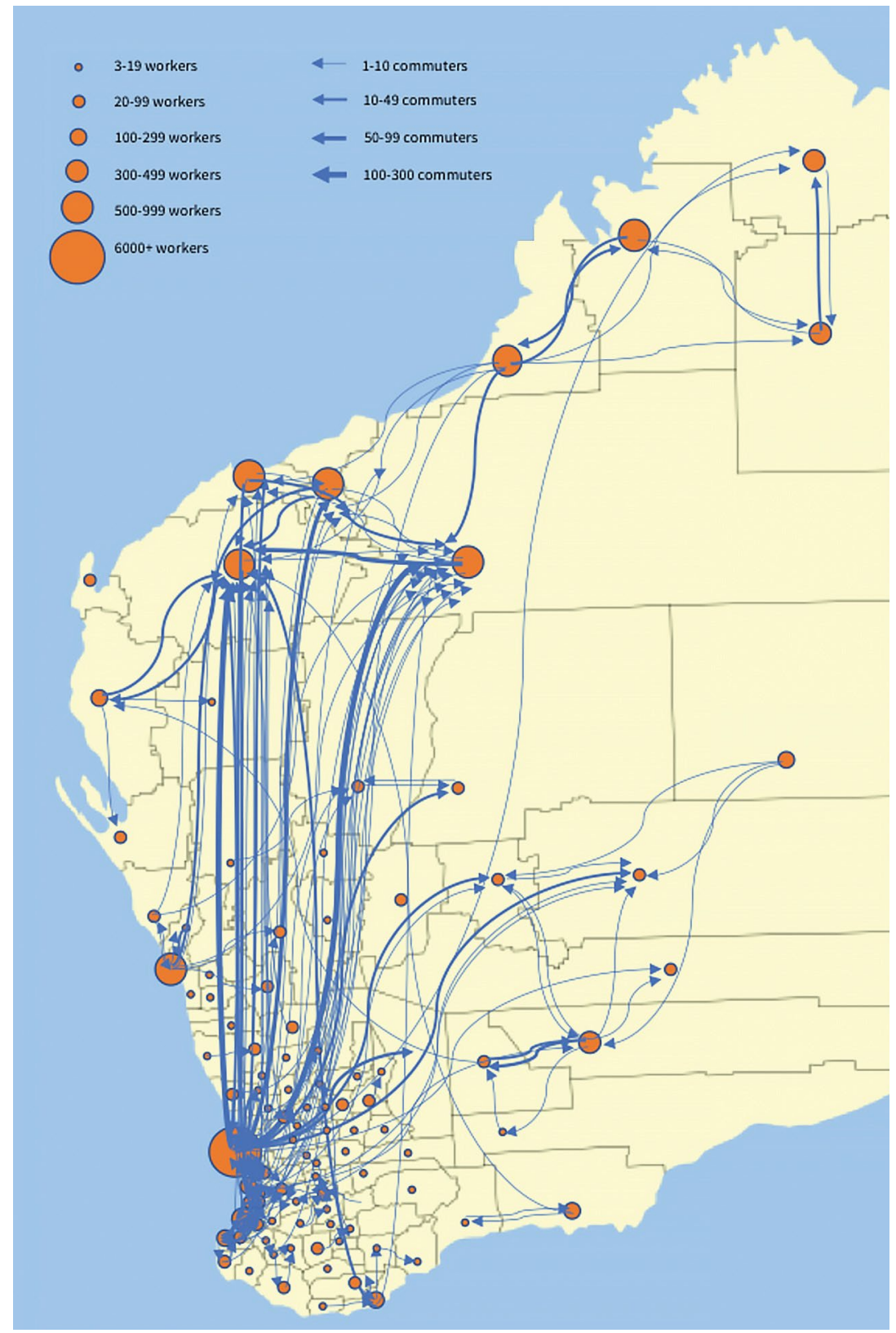

Figure 10.1: Indigenous workforce mobility, 2016.

Note: Arrows and dots are positioned randomly within LGAs on the map to show the flow of movement, not precise locations.

Source: Produced by the authors from 2016 Census data comparing local government area (LGA) of usual residence with place of work LGA. 


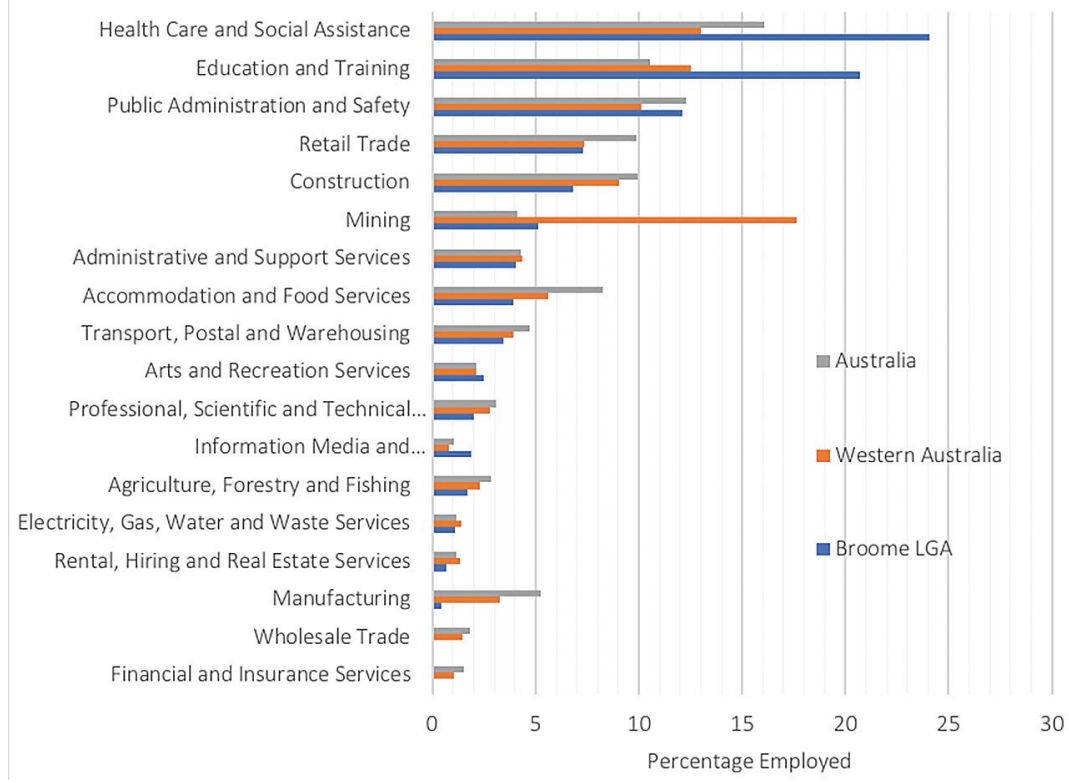

Figure 10.2: Indigenous employment by industry, 2016.

Source: Australian Bureau of Statistics.

Like the rest of Australia, a much higher proportion of Indigenous workers in the Shire of Broome are engaged in the health and education sectors, as well as public administration. This is perhaps partially explained by the fact that Broome is the largest service centre in the Kimberley region and the hub of public and independent health, education and justice services for the entire region. Given that there are no local mining operations within the shire, Indigenous mining employees there are likely to be part of the FIFO workforce.

\section{Origins of Indigenous FIFO in Broome}

Indigenous FIFO work is a relatively recent phenomenon in Australia. Though the iron ore industry existed in the country prior to the 1960s, it contributed relatively little to the nation's GDP. After 1976, there was a considerable upsurge in exploration in mining, and this coincided with the introduction of the Aboriginal Land Rights (Northern Territory) Act 1976. Cousins and Nieuwenhuysen ${ }^{35}$ note that these circumstances

35 Cousins and Nieuwenhuysen, Aboriginals and the Mining Industry. 
began to focus sustained attention on the relationship between Indigenous communities and the extractive industries for, perhaps, the first time. Since then, a large and important scholarly literature has traced the oftenfraught relationship between the mining industry and Indigenous peoples rights and interests. ${ }^{36}$ Of particular relevance to the present case study is the significant shift that occurred at a national level in respect of the impetus for Indigenous inclusion in the mining workforce following the High Court determination in Mabo v. Queensland 1992 and the subsequent passage of the national Native Title Act 1993.

Though the Native Title Amendment Act 1998 weakened the provisions of the 1993 Act, these laws require mining companies to negotiate with native title holders and registered claimants, negotiate compensation for loss of native title rights and interests and/or share some benefits with the relevant Indigenous native title group $(s){ }^{37}$ The mining industry was initially antagonistic to the notion of native title, ${ }^{38}$ but eventually accepted the obligation to engage with Indigenous peoples. ${ }^{39}$ As Langton and Mazel note, mining companies are motivated to 'reach agreement with local traditional Aboriginal owners to avoid costly litigation and delays to exploration and mining projects'. ${ }^{40}$

As these Acts of Parliament began to take effect, resource companies were also facing increasing global pressure to demonstrate a higher standard of ethical engagement with the communities directly affected by their operations. Expensive delays due to local protests and unrest at extraction sites led many mining companies to begin to engage in 'risk mitigation' strategies under the broad banner of 'corporate social responsibility' (CSR). CSR is often couched in terms of companies recognising the 'right

36 For example, Altman and Martin, Power, Culture, Economy; Weiner and Glaskin, Customary Land Tenure; Howitt, Connell and Hirsh, Resources, Nations; O'Faircheallaigh, 'Extractive Industries'; Langton, 'The Resource Curse'; Wand and Harvey, 'The Sky Did Not Fall In'.

37 There is significant debate about the effect that native title legislation has had on Indigenous Australians. Some commentators and scholars argue that the effects have been broadly very positive and empowering for Indigenous peoples, providing them with a legitimacy and political voice they previously were not afforded. Others are less convinced. They highlight the deeply colonial premises and processes for claiming and proving the legitimate existence of native title, the grave deficit of resourcing to properly administer native title rights, including negotiation processes with large, multinational mining companies, and the complex local politics of representation and legitimacy that emerge out of the native title process (see Prout Quicke et al., Aboriginal Assets, for a recent overview of these concerns).

38 Langton and Mazel, 'Poverty in the Midst of Plenty'.

39 Wand and Harvey, 'The Sky Did Not Fall In'.

40 Langton and Mazel, 'Poverty in the Midst of Plenty', Poverty in the Midst of Plenty, 44. 
thing to do'; however, as Langton and Mazel, ${ }^{41}$ Trebeck, ${ }^{42}$ and Harvey ${ }^{43}$ explain, this is always envisaged within the context of creating value for shareholders. The new operating paradigm for business, especially publicly listed companies whose practices are more easily scrutinised now than ever before, is profit-making, but within wider prerequisites that satisfy key audiences' perceptions of ethical and responsible corporate behaviours. ${ }^{44}$

In Australia, native title agreement-making processes and CSR imperatives for extractive companies often include Aboriginal employment targets. Resource companies legitimise their 'social licence to operate' by enhancing employment relationships with Aboriginal workers. ${ }^{45}$ However, for a number of reasons, these quotas cannot always be fulfilled through local labour. As Haslam McKenzie and Hoath explain, these reasons may relate to reduced employability of local Aboriginal people as a result of the inaccessibility of requisite education and training opportunities; cultural objections to working for extractive industries that 'interfere with country' for which they have spiritual responsibility; a lack of job brokers that strengthen Indigenous linkages with, and within, the mainstream economy; the incompatibility of shift work with cultural obligations; and logistical obstacles such as the lack of a drivers licence. ${ }^{46}$ As a result, some companies introduced FIFO operations that target Indigenous peoples living remotely from mine sites to fulfil Indigenous employment quotas or targets. ${ }^{47}$

\section{The Mining Boom and Rio Tinto}

The period 2001-14 was characterised by a sustained resources boom in Australia, and Western Australia, as a state endowed with significant mineral deposits, was a major driving force. Over this period, there was a high demand for lower skilled and experienced labour in the mining industry and those industries that service it. Exceptionally strong jobs growth associated with the mining boom progressively and steadily tightened the labour market from 2002. At its lowest point in late 2008, Western Australia's unemployment rate dropped to 2.2 per cent. ${ }^{48}$

41 Langton and Mazel, 'Poverty in the Midst of Plenty'.

42 Trebeck, 'Tools for the Disempowered?'.

43 Harvey, 'Social Development'.

44 Trebeck, 'Tools for the Disempowered?'.

45 Hunter, 'Recent Growth in Indigenous'; Tiplady and Barclay, 'Indigenous Employment'.

46 Haslam McKenzie and Hoath, 'Aboriginal Mine Workers'.

47 Scambary, My Country, Mine Country; Taylor and Scambary, 'Indigenous People and the Pilbara'.

48 Australian Bureau of Statistics, 'Unemployment (Cat. 6202)'. 
Concentrated extractive operations in the Pilbara region required much larger labour forces than could be supplied from the relatively small local regional populations. FIFO arrangements were intensified to harness larger metropolitan labour markets. In 2006, one transnational mining company, Rio Tinto, pioneered the use of directly flying employees from specific regional Western Australian towns to Pilbara mine sites. Since then, the practice has expanded so that, in 2016, about 16 per cent of the Rio Tinto FIFO workforce commuted directly from a total of eight regional Western Australian centres, including the Shire of Broome, to seven Rio Tinto mining operations in the Pilbara.

The expansion of mining and corporate commitments regarding Aboriginal employment in mining has been instrumental in the increase of Aboriginal employment, especially in remote areas with major mines. ${ }^{49}$ From 2001 to 2008, the resources boom saw overall unemployment rates drop dramatically in Western Australia. As Figure 10.3 shows, the trends were similar for both Indigenous and non-Indigenous Western Australians. During the height of the boom, in some remote and very remote areas, and at specific sites, Aboriginal workers accounted for up to 40 per cent of those directly employed or employed through contractors. ${ }^{50}$

However, employment data also show that, while there was a considerable increase in the number of Indigenous people employed in remote mine operations, only a proportion, and often only a small number, of that labour force are local to remote areas. ${ }^{51}$ Since filling Indigenous employment quotas from near-mine communities is not always possible, companies can seek to meet their native title Indigenous employment targets, and/or pursue their CSR agendas related to Indigenous employment, by employing Aboriginal people from elsewhere through FIFO arrangements and, specifically, through programs such as Rio Tinto's Regional Workforce Strategy. Aboriginal employees arrive on mine sites after being trained for work in the mining industry through work readiness programs, industry-supported apprenticeships and dedicated training organisations. Increasing Indigenous engagement in regional FIFO employment has been a particular focus for Rio Tinto. Today, 23.6 per cent of the company's total Indigenous workforce are from regional towns.

49 Hunter, Howlett and Gray, 'The Economic Impact of the Mining Boom'.

50 Australian Bureau of Statistics, 'Labour Force Characteristics'.

51 Australian Bureau of Statistics, 'Labour Force Characteristics'. 

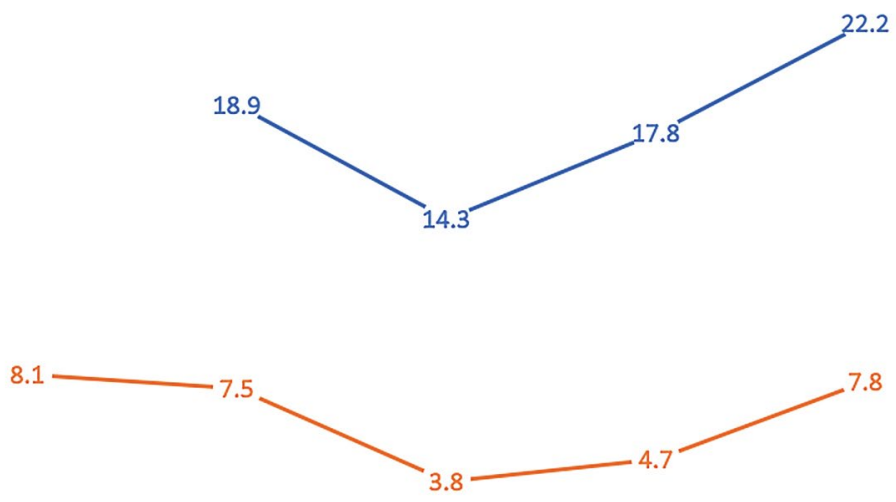

$\begin{array}{llrr}2001 & 2006 & 2011 & 2016 \\ & -- \text { Indigenous WA } & - & - \text { Whole of WA }\end{array}$

Figure 10.3: Change in unemployment rates, 1996-2016.

Source: Authors' calculations based on 1996-2016 Indigenous Labour Force Status (Usual Residence) census data.

In Broome, 90 per cent of the Rio Tinto FIFO workforce is Indigenous, and usually works two weeks onsite with one week off at home (known as the $2 \mathrm{x} 1$ swing) at one of the company's three Pilbara-based mining operations. In the section that follows, we present findings from a 2016 study of Indigenous Rio Tinto FIFO workers and related stakeholders in the Shire of Broome (including the town of Broome and communities along the Dampier Peninsula), which analysed the experience and effects of FIFO work. In total, 32 participants engaged in interviews or focus groups regarding their experiences, interests and concerns with respect to Rio Tinto's FIFO operations out of Broome.

\section{Experiences of Indigenous FIFO Workers in Broome}

Historically, mobile Indigenous labourers in Australia experienced financial expropriation and exploitative/abusive working conditions as a matter of course. Such practices were justified, normalised or simply overlooked as frontier development rested on the discourse of Social Darwinism and an absence of legal protections for Indigenous workers. While capitalist 
accumulation strategies certainly undergird contemporary employee labour mobility practices in the mining sector in Australia, financial expropriation for Indigenous FIFO workers is today comparatively limited. It is a highly formalised, highly regulated and highly paid sector. In Broome, a respected local Indigenous Rio Tinto employee oversees all recruitment, training and ongoing community relations activities for Indigenous employees. Employees and their families identified her as their 'go-to' person for dealing with a range of concerns and problems. They explained that they were comfortable talking to her because 'she is one of us, she understands'.

In addition to managing and funding most recruitment and community relations work internally, Rio Tinto also developed and supports a range of training and skill development programs for prospective employees, as well as mentoring work-ready and apprenticeship employment pathways for local people. Rio Tinto bears most of the cost associated with employment-brokering processes.

Many participants described employment with Rio Tinto as highly sought after by local Aboriginal people in Broome. This favourable disposition is likely, in some measure, a product of the fact that the company's operational 'footprint' in the Shire of Broome is only positive. There are no active mines in the region that have the potential to cause damage to country or produce negative externalities and serious social costs, such as have been experienced in the Pilbara. In Broome, the company financially supports a range of local community initiatives and events. It is also likely due, in some measure, to the company's attempts over several decades to build stronger relationships with local Indigenous communities in the Kimberley through strategic investments and training and employment programs. Employees and their families also described a range of financial and social 'status' benefits associated with working for Rio Tinto. Some noted that working for a large multinational company that has a strong safety record, and a reputation for looking after its employees with high salaries, comfortable accommodation and good industrial conditions, was viewed as a pinnacle employment opportunity. Representatives from training organisations explained that trainees wearing a Rio Tinto highvisibility shirt 'walked taller wearing it'. Aboriginal corporations and other local organisations viewed Rio Tinto employees as potential role models and future mentors for others in the community because they had been well trained and are respected by others in the community. 
Further, many research participants claimed that the multicultural history and heritage of long-term Broome residents, and the coexistence of Indigenous cultural practice with mainstream education and employment, has fostered positive attitudes towards mainstream work. A number of interviewees claimed that the influence of mission teaching and the interaction between many cultures, both in the workplace and socially, has produced a strong and enduring work ethic, valuing of reliable work and culture of worker reliability among the multicultural Broome population.

Nevertheless, the fracturing legacies of colonisation are also still evident throughout the Shire of Broome and contribute to certain forms of economic precarity and challenging working conditions that underpin Indigenous FIFO work. Historical experiences of segregation and workplace brutality have promulgated intergenerational disadvantage in Broome. The prevalence of neoliberalism as the prevailing ideology for policy development over the last 30 years has also resulted in the steady withdrawal and rationalisation of numerous government programs that service remote communities across the Kimberley. Broomehasconsequently become home, if temporarily, to a range of Indigenous people from across the region who have experienced multiple forms of disadvantage and/or disturbance. This includes those that require access to justice, counselling and health services, those dislocated from their customary homelands, and those experiencing conflict within their homeland communities. ${ }^{52}$ A lack of suitable accommodation creates additional layers of complexity and hardship, creating opportunities for increased conflict and antisocial behaviour. By comparison to the non-Aboriginal population, health and wellbeing indicators are persistently low. While the physical beauty of Broome and the Kimberley can be mesmerising, there is an undercurrent of disadvantage for many Indigenous people.

The intergenerational effects of living in this (post)colonial landscape mean that many Indigenous people in the region have experienced greater challenges in accessing mainstream education and employment markets. Unsurprisingly then, both in the Shire of Broome and in Western Australia more generally, Indigenous mining employees tend to occupy lower skilled positions within the industry. As Figure 10.4 shows, at the 2016 census, the overwhelming majority of Indigenous mining employees were either machinery operators, drivers, technicians or trade workers and labourers. 
Less than 10 per cent of the overall Western Australian Indigenous mining workforce were professionals and managers. This profile mirrors that of the Indigenous FIFO workers who participated in the study-most were machinery operators and drivers or mechanics-and also mirrors earlier research findings from Scambary. ${ }^{53}$

While very few jobs in the mining industry could be described as unskilled, and while all of the participants in the study had either undergone a rigorous training program or had prior employment experience in requisite roles, many participants identified a high degree of uncertainty regarding the security of their jobs. As actors in an extractive company operating in a volatile global commodities market, employees of Rio Tinto, and the communities in which it invests, are also subject to a degree of volatility and precarity. For Indigenous FIFO workers, it is the precarity of employment instability in a sector that is both highly sensitive to global market demand and rapidly embracing automation technologies that eliminate the need for lower skilled workers.

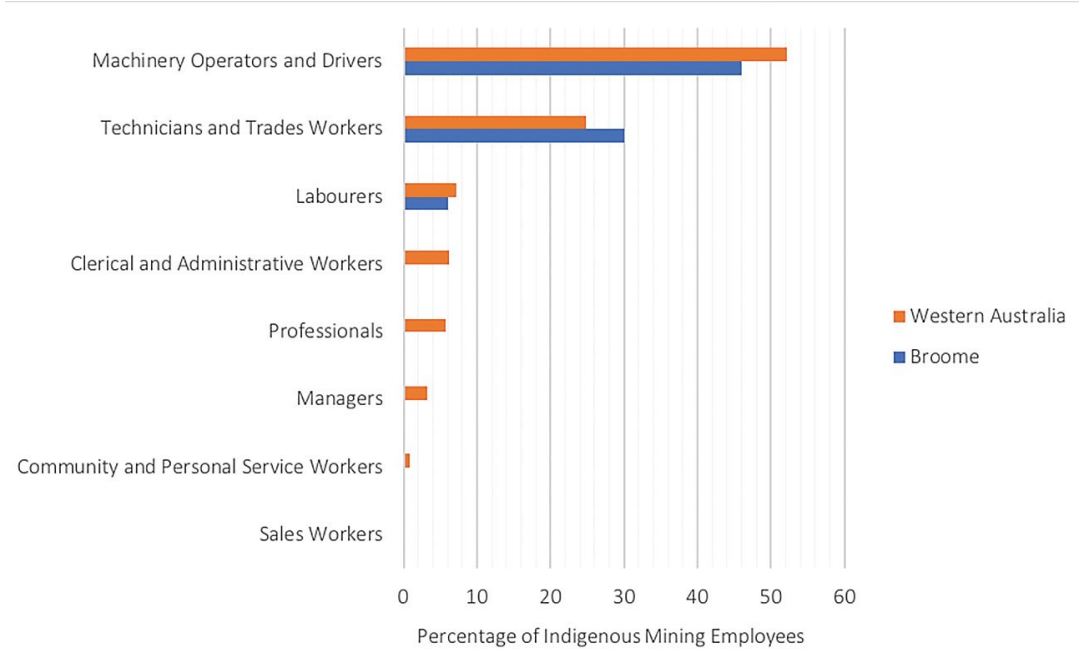

Figure 10.4: Indigenous occupations within the Western Australian mining sector, 2016.

Source: Australian Bureau of Statistics, 'Indigenous Occupations'.

53 Scambary, My Country, Mine Country. 
Numerous participants identified a perception that the pathways to career progression with Rio Tinto were difficult to access. 'The purple circle' has been a recurring theme in research regarding the socio-economic effects of FIFO in regional Western Australia ${ }^{54}$ and some participants in the Broome study described a similar phenomenon, in which supervisors used a variety of interpersonal skills and prohibition of opportunities to sideline employees who were viewed to be recalcitrant. These included withholding information, favouritism regarding shifts and rosters, and denying opportunities for promotion and learning new machines. Some Broome-based employees commented on the perceived tolerance of unfair practices, though they did not explicitly attribute these to institutionalised racism or a systemic neo-colonial orientation within the company. Nevertheless, due to their disproportionate occupation of lower skilled jobs with the company, Indigenous employees can be disproportionately affected by these practices when they occur.

Many participants felt vulnerable to automation and redundancy during the period of downturn that has characterised the post-2014 resources sector in Western Australia, and this has inhibited their ability to plan for their futures. For example, those who start their employment term in public housing quickly find their salary moving them above the eligibility threshold to remain tenants of the state. When this occurs, they must find new housing arrangements. However, housing costs in Broome are extraordinarily high and there is a limited private housing market. Further, Indigenous peoples often face discrimination within the housing market. Where employees have secured housing in the private market, the risk of redundancy increases their vulnerability to housing cost pressures. Public housing waiting lists are long and, in small communities within the shire, alternative housing is not easily attained and household crowding is a common problem. This uncertainty can extend to other avenues of expenditure and investment and work against long-term planning. Will school fees become unaffordable? Can the vehicle finance continue to be serviced? While many of these uncertainties are common to mining employees regardless of their Indigenous status, discrimination and cultural attachments to country and kin can add additional layers

54 Haslam McKenzie, 'Are There Enduring'; Davies, Maru and May, 'Enduring Community Value'; Heiler and Pickersgill, 'Shiftwork and Rostering Arrangements'. 
of complexity to answering these kinds of questions for Indigenous FIFO employees. They may feel less able or inclined to simply relocate to larger job markets in search of alternative employment. ${ }^{55}$

Other significant onsite challenges associated with FIFO work were also identified. ${ }^{56}$ Some of these are common to all FIFO workers and some are unique to Indigenous workers. Rostered FIFO swings on long shifts (usually 12 hours) in male-dominated mining camps located in remote areas with arid climates are exacting for all workers. Indigenous employees and their families interviewed in this study had differing perspectives on what kind of roster rotation they felt best served their circumstances. However, all described it as physically, emotionally and mentally challenging. While most employees interviewed believed they had been adequately prepared for the mine site, all agreed that nothing can prepare an employee for 12-hour shifts, the number of unknown people or the scale of the mine site. The training programs, they indicated, did not adequately prepare for fatigue management.

Rio Tinto has argued that fierce competition for labour within the industry has generated vastly improved camp conditions for employees and generous remunerations packages, and that longer shifts allow employees more time at home with their families at the end of their intensive swings. ${ }^{57}$ While market competition may have produced some improvements in conditions for workers, the make-up of swings, shift lengths and mine site worker conditions all remain the purview of the company, and many employees who participated in the study described the levels of mental, physical and emotional fatigue associated with these arrangements as acute.

A second key challenge at the employee-employer interface that Indigenous workers identified related to managing and maintaining their cultural obligations while in the employment of a multinational mineral extraction company. For most, these challenges manifest in respect of obligations to their home communities. Compassionate leave and cultural leave were important for meeting bereavement and ceremonial obligations. Indigenous employees appreciated that this was accepted as

55 Hunter, Howlett and Gray, 'The Economic Impact of the Mining Boom'; Haslam McKenzie and Hoath, 'Aboriginal Mine Workers'.

56 In this chapter, we focus in particular on the employee/employer interface, though we note that a range of off-site challenges associated with social reproduction were also raised.

57 Rio Tinto, 'Submission to the House of Representatives'. 
legitimate leave. However, many considered three days per year inadequate, especially as flights in and out of Broome were not likely to coincide with the times of bereavement, meaning that employees must take additional time as annual or unpaid leave. Further, employees noted that family members did not always understand that company policy cannot be bent or changed for individuals, which sometimes caused heightened tension within families already dealing with loss and associated trauma.

Some participants described a level of cultural distress related to being involved in extractive activities on the customary homelands of other Indigenous peoples. Disturbing the ground is an activity considered particularly culturally sensitive within Indigenous relational ontologies that encompass country. Where employees reported related concerns, Aboriginal support officers (ASO) and mentors onsite played a critical role. Several interviewees recounted an experience in which Aboriginal employees regularly saw a spirit person and felt a negative spiritual presence. The ASO helped to explain the situation to the company and organised a smoking ceremony. The company was reported to have taken these concerns very seriously and senior management supported the necessary cultural protocols to appropriately respond. Other interviewees described the significance of smoking ceremonies onsite and the role of ASOs in not only organising them, but also communicating the importance of these rituals to others in the company.

\section{Conclusion}

We commenced with the assertion that Indigenous labour mobility has received marginal (at best) scholarly attention in Australia. It has been under-examined and under-theorised by economists, geographers and other social scientists. This study begins the process of exploring the costs and benefits associated with one type of work-related mobility for Indigenous people. The empirical findings presented highlight the uniqueness of Indigenous FIFO work as a form of Indigenous labour mobility within Australian history. It is distinct from the precarious and often-exploitative unskilled labour mobilities characteristic of much labour mobility in the early colonial period. Indigenous employment in this case study is politically important to Rio Tinto and, therefore, labour mobility is intentionally facilitated, and paid for, by the company. Indigenous mainstream labourers now have protections under Australia's legal code, unlike many international labour migrants. 
However, Indigenous FIFO work is inextricably linked to the coloniality of power in at least two key ways. First, this kind of labour is politically important to resource companies not just because of their need, and even desire, to secure a social licence to operate, but also because of a legal apparatus in Australia - the native title system - that requires companies to negotiate compensation and benefits, such as employment opportunities, with native title groups. However, the native title system is a function of Crown law, and requires Indigenous peoples to represent themselves in ways that are legible to the settler state, while, at the same time, proving cultural distinctiveness. Even when such proofs have been accepted by the Crown, the very reality of FIFO work is evidence that agreement-making processes are not always able to secure employment benefits for the native title groups with whom such agreements are made. Second, evidence suggests that many FIFO workers are lower skilled employees who are most vulnerable to increases in technological automation and fluctuations in global commodity prices. Arguably, a large part of the reason for this is that Indigenous Australians tend to have lower levels of educational attainment and higher levels of overall disadvantage. Such circumstances link directly to colonial processes of dislocation, marginalisation and exclusion.

\section{Bibliography}

Altman, Jon. 'Indigenous Policy: Canberra Consensus on the Neoliberal Project of Improvement'. In Australian Public Policy: Progressive Ideas in the Neoliberal Ascendency, edited by L. Orchard and C. Miller, 115-32. Bristol: Policy Press, 2014. doi.org/10.2307/j.ctt1ggjk39.13.

'What Future for Remote Indigenous Australia? Economic Hybridity and the Neoliberal Turn'. In Culture Crisis: Anthropology and Politics in Aboriginal Australia, edited by J. Altman and M. Hinkson, 259-80. Sydney: UNSW Press, 2010.

Altman, Jon and D Martin, eds. Power, Culture, Economy: Indigenous Australia and Mining. CAEPR Research Monograph No. 30. Canberra: ANU E Press, 2009. doi.org/10.22459/CAEPR30.08.2009.

Anthony, T. 'An Anniversary Shrouded in Myths'. Analysis \& Policy Observatory, 22 August 2006, apo.org.au/node/5924.

Australian Bureau of Statistics. 'Indigenous Employment by Industry, 2016'. Canberra: Australian Bureau of Statistics, Tablebuilder, 2017. 
'Indigenous Occupations - Broome and Whole of WA, 2016'. Canberra: Australian Bureau of Statistics, Tablebuilder, 2017.

- 'Labour Force Characteristics of Aboriginal and Torres Strait Islander Australians, Estimates from the Labour Force Survey 2011'. Canberra: Australian Bureau of Statistics, 2012.

_. 'Unemployment (Cat. 6202)'. Canberra: Australian Bureau of Statistics, 2009.

Biddle, N. 'Indigenous Migration and the Labour Market: A Cautionary Tale'. Australian Journal of Labour Economics 13, no. 3 (2010): 313-30.

—. 'Proximity to Labour Markets: Revisiting Indigenous Employment through an Analysis of Census Place of Work Data'. Australian Journal of Labour Economics 13, no. 2 (2010): 75-89.

Blunt, A. 'Cultural Geographies of Migration: Mobility, Transnationality and Diaspora'. Progress in Human Geography 31, no. 5 (2007): 684-94. doi.org/ $10.1177 / 0309132507078945$.

Bolton, G. 'Alexander Forrest's Expedition 1879 and Early Development of the Cattle Industry'. In Kimberley History: People, Exploration and Development, edited by C. Clement, J. Gresham and H. McGlashan, 101-10. Perth: Kimberley Society, 2012.

Buckley, M., S. McPhee and B. Rogaly. 'Labour Geographies on the Move: Migration, Migrant Status and Work in the 21st Century'. Geoforum 78 (2017): 153-58. doi.org/10.1016/j.geoforum.2016.09.012.

Choo, C. 'Mixed Blessings: Establishment of Christian Missions in the Kimberley'. In Kimberley History: People, Exploration and Development, edited by C. Clement, J. Gresham and H. McGlashan, 195-214. Perth: Kimberley Society, 2012.

Commonwealth of Australia. 'Closing the Gap Prime Minister's Report 2018'. Canberra: Commonwealth of Australia, 2018.

Cousins, D. and J. Nieuwenhuysen. Aboriginals and the Mining Industry. Sydney: Allen and Unwin, 1984.

Cresswell, Tim, Sara Dorow and Sharon Roseman. 'Putting Mobility Theory to Work: Conceptualizing Employment-Related Geographical Mobility'. Environment and Planning A: Economy and Space 48, no. 9 (2016): 1787-803. doi.org/10.1177/0308518X16649184.

Curchin, K. 'Interrogating the Hybrid Economy Approach to Indigenous Development'. Australian Journal of Social Issues 48, no. 1 (2013): 15-34. doi.org/10.1002/j.1839-4655.2013.tb00269.x. 
'Two Visions of Indigenous Economic Development and Cultural Survival: The "Real Economy" and the "Hybrid Economy". Australian Journal of Political Science 50, no. 3 (2015): 412-26. doi.org/10.1080/10361146. 2015.1049976.

Davies, J., Y. Maru and T. May. 'Enduring Community Value from Mining: Conceptual Framework'. In CRC-REP Working Paper CW007. Alice Springs: Ninti One Limited, 2012.

Dockery, M. 'A Wellbeing Approach to Mobility and Its Application to Aboriginal and Torres Strait Islander Australians'. Social Indicators Research 125, no. 1 (2016): 243-55. doi.org/10.1007/s11205-014-0839-8.

Gray, M., B. Hunter and S. Lohoar. 'Increasing Indigenous Employment Rates: Issues Paper No 3'. In Closing the Gap Clearinghouse, edited by Australian Institute of Health and Welfare. Canberra: Commonwealth of Australia, 2012 .

Hart, A., K. Travaille, R. Jones, S. Brand-Gardner, F. Webster, A. Irving and A. Harry. 'Western Australian Silver-Lipped Pearl Oyster (Pinctada Maxima) Industry'. In Western Australian Marine Stewardship Council Report Series No. 5. Perth: Government of Western Australia Department of Fisheries, 2016.

Harvey, Bruce. 'Social Development Will Not Deliver Social Licence to Operate for the Extractive Sector'. The Extractive Industries and Society 1, no. 1 (2014): 7-11. doi.org/10.1016/j.exis.2013.11.001.

Haslam McKenzie, F. 'Are There Enduring Community Values from Mining for Aboriginal People in the Pilbara?. Journal of Australian Indigenous Issues 17, (2014): 91-107.

Haslam McKenzie, F. and A. Hoath. 'Aboriginal Mine Workers: Opportunities and Challenges of Long Distance Commuting'. In Labour Force Mobility in the Australian Resources Industry: Socio-Economic and Regional Impacts, edited by F. Haslam McKenzie, 157-70. Singapore: Springer, 2016. doi.org/ 10.1007/978-981-10-2018-6_9.

Heiler, K. and R. Pickersgill. 'Shiftwork and Rostering Arrangements in the Australian Mining Industry: An Overview of Key Trends'. Australian Bulletin of Labour 27, no. 1 (2001): 20-42.

Howitt, R., J. Connell and P. Hirsh, eds. Resources, Nations and Indigenous Peoples. Melbourne: Oxford University Press, 1996.

Hunter, B. 'Recent Growth in Indigenous Self-Employed and Entrepreneurs'. In CAEPR Working Paper No. 91. Centre for Aboriginal Economic Policy Research, The Australian National University, 2013. 
Hunter, B., M. Howlett and M. Gray. 'The Economic Impact of the Mining Boom on Indigenous and Non-Indigenous Australians'. In CAEPR Working Paper No. 93. Canberra: Centre for Aboriginal Economic Policy Research, The Australian National University, 2014.

Keen, I. 'Introduction'. In Indigenous Participation in Australian Economies: Historical and Anthropological Perspectives, edited by I. Keen, 1-23. Canberra: ANU E Press, 2010. doi.org/10.22459/IPAE.12.2010.01.

Kelly, S. Proud Heritage. Broome: Kimbooks Publishing, 1999.

King, Russell. 'Geography and Migration Studies: Retrospect and Prospect'. Population, Space and Place 18, no. 2 (2012): 134-53. doi.org/10.1002/ psp.685.

Langton, M. 'The Resource Curse'. In The Griffith Review 28, griffithreview.com/ articles/the-resource-curse/.

Langton, M. and O Mazel. 'Poverty in the Midst of Plenty: Aboriginal People, the 'Resource Curse' and Australia's Mining Boom'. Journal of Energy \& Natural Resources Law 26, no. 1 (2015): 31-65. doi.org/10.1080/0264681 1.2008.11435177.

Lockyer, B. Last Truck Out. Broome: Magabala Books, 2009.

Lydon, J. 'Picturing Macassan-Australian Histories'. In Indigenous Networks: Mobility, Connections and Exchange, edited by Jane Carey and Jane Lydon, 140-66. Hoboken: Routledge, 2014. doi.org/10.4324/9781315766065-7.

McDowell, L. 'The Lives of Others: Body Work, the Production of Difference, and Labour Geographies'. Economic Geography 91, no. 1 (2015): 1-23. doi.org/ 10.1111/ecge. 12070 .

Musharbash, Y. Yuendumu Everyday: Contemporary Life in Remote Aboriginal Australia. Canberra: Aboriginal Studies Press, 2008.

O'Faircheallaigh, C. 'Extractive Industries and Indigenous Peoples: A Changing Dynamic?'. Journal of Rural Studies 30, (2013): 20-30. doi.org/10.1016/ j.jrurstud.2012.11.003.

Preibisch, K. 'Pick-Your-Own Labour: Migrant Workers and Flexibility in Canadian Agriculture'. International Migration Review 44, no. 2 (2010): 404-41. doi.org/10.1111/j.1747-7379.2010.00811.x.

Productivity Commission. Geographic LabourMobility. Canberra: Commonwealth of Australia Productivity Commission, 2014. 
Prout, S. 'Interrogating the Image of the Wondering Nomad'. In Aboriginal Populations: Social, Demographic, and Epidemiological Perspectives, edited by F. Trovato and A. Romanuik, 381-414. Edmonton: University of Alberta Press, 2014.

' 'Urban Myths: Exploring the Unsettling Nature of Aboriginal Presence in and through a Regional Australian Town'. Urban Policy and Research 29, no. 3 (2011): 275-91. doi.org/10.1080/08111146.2011.578300.

Prout, S. and R. Howitt. 'Frontier Imaginings and Subversive Indigenous Spatialities'. Journal of Rural Studies 25, (2009): 396-403. doi.org/10.1016/ j.jrurstud.2009.05.006.

Prout Quicke, S. M. Dockery and A. Hoath. Aboriginal Assets: The Impact of Major Mining Agreements Associated with Native Title in Western Australia. Curtin University and the University of Western Australia, 2017.

Redmond, A. 'Tracking Wurnan: Transformations in the Trade and Exchange of Resources in the Northern Kimberley'. In Indigenous Participation in Australian Economies II: Historical and Anthropological Perspectives, edited by I. Keen, 5772. Canberra: ANU E Press, 2012. doi.org/10.22459/IPAE.07.2012.03.

Redmond, A. and F. Skyring. 'Exchange and Appropriation: The Wurnan Economy and Aboriginal Land and Labour at Karunjie Station, NorthWestern Australia'. In Indigenous Participation in Australian Economies: Historical and Anthropological Perspectives, edited by I. Keen, 73-90. Canberra: ANU E Press, 2010. doi.org/10.22459/IPAE.12.2010.05.

Rio Tinto. 'Submission to the House of Representatives Standing Committee on Regional Australia'. In Inquiry into the Use of Fly-In Fly-Out (FIFO) and Drive-In Drive-Out (DIDO) Work Practices in Regional Australia. Canberra: Parliament of Australia, 2011.

Roseman, S., P. Barber and B. Neis. 'Towards a Feminist Political Economy Framework for Analyzing Employment-Related Geographical Mobility'. Studies in Political Economy 95, no. 1 (2016): 175-203. doi.org/10.1080/ 19187033.2015.11674951.

Russell, L. “The Singular Transcultural Space”: Networks of Ships, Mariners, Voyagers and "Native" Men at Sea, 1790-1870'. In Indigenous Networks: Mobility, Connections and Exchange, edited by Jane Carey and Jane Lydon, 97-113. Hoboken: Routledge, 2014. doi.org/10.4324/9781315766065-5.

Scambary, B. My Country, Mine Country: Indigenous Peoples, Mining and Development Contestation in Remote Australia. CAEPR Monograph No. 33, Canberra: ANU Press, 2013. doi.org/10.22459/CAEPR33.05.2013. 
Sheller, M. and J. Urry. 'The New Mobilities Paradigm'. Environment and Planning A 38, (2006): 207-26. doi.org/10.1068/a37268.

Silvey, R. 'Power, Difference and Mobility: Feminist Advances in Migration Studies'. Progress in Human Geography 28, no. 4 (2004): 490-506. doi.org/ 10.1191/0309132504ph490oa.

Skyring, F. 'Low Wages, Low Rents, and Pension Cheques: The Introduction of Equal Wages in the Kimberley, 1968-1969'. In Indigenous Participation in Australian Economies II: Historical Engagements and Current Enterprises, edited by N. Fijn, I. Keen, C. Llyod and M. Pickering, 153-69. Canberra: ANU E Press, 2012. doi.org/10.22459/IPAE.07.2012.08.

Stevens, F. Aborigines in the Northern Territory Cattle Industry. Canberra: Australian Nationa University Press, 1974.

Taylor, J. and M. Bell, eds. Population Mobility and Indigenous Peoples in Australasia and North America. London: Routledge, 2004.

Taylor, J. and B. Scambary. 'Indigenous People and the Pilbara Mining Boom: A Baseline for Regional Participation'. In Research Monograph No. 25. Canberra: Centre for Aboriginal Economic Policy Research, The Australian National University, 2005.

Taylor, J. 'Population and Diversity: Policy Implications of Emerging Indigenous Demographic Trends'. Canberra: Centre for Aboriginal Economic Policy Research, The Australian National University, 2006.

Tiplady, J. and M. Barclay. 'Indigenous Employment in the Australian Minerals Industry'. St Lucia: Centre for Responsible Mining, University of Queensland, 2007.

Trebeck, K. 'Tools for the Disempowered? Indigenous Leverage over Mining Companies'. Australian Journal of Political Science 42, no. 4 (2007): 541-62. doi.org/10.1080/10361140701513604.

Wand, P. and B. Harvey. 'The Sky Did Not Fall In? Rio Tinto after Mabo'. In The Limits of Change: Mabo and Native Title 20 Years On, edited by T. Bauman and L. Glick, 289-309. Canberra: Australian Institute for Aboriginal and Torres Strait Islander Studies Press, 2012.

Weiner, J. and K. Glaskin, eds. Customary Land Tenure and Registration in Australia and Papua New Guinea: Anthropological Perspectives. Canberra: ANU E Press, 2007. 
This text is taken from Labour Lines and Colonial Power: Indigenous and Pacific Islander Labour Mobility in Australia, edited by Victoria Stead and Jon Altman, published 2019 by ANU Press, The Australian National University, Canberra, Australia.

doi.org/10.22459/LLCP.2019.10 